\title{
MAGUK p55 Subfamily Member 2
}

National Cancer Institute

\section{Source}

National Cancer Institute. MAGUK p55 Subfamily Member 2. NCI Thesaurus. Code C33994.

MAGUK p55 subfamily member 2 ( $576 \mathrm{aa}, \sim 65 \mathrm{kDa}$ ) is encoded by the human MPP2 gene. This protein is involved in the regulation of cell proliferation and cell-cell junction formation. 